\title{
KLASIFIKASI KAWASAN PERMUKIMAN TINGKAT KELURAHAN UNTUK PEMBANGUNAN SISTEM BERBASIS DATA KUALITAS PERMUKIMAN (STUDI KASUS: 67 KELURAHAN DI KOTA BENGKULU)
}

\author{
Rizki Setiawan ${ }^{1}$ Ernawati $^{2}$, Rusdi Efendi ${ }^{3}$ \\ ${ }^{1,2,3}$ Program Studi Teknik Informatika, Fakultas Teknik, Universitas Bengkulu. \\ Jl. W.R. Supratman Kandang Limun Bengkulu 38371A INDONESIA \\ (telp: 0736-341022; fax: 0736-341022) \\ ${ }^{1}$ rizki.setiawan95@gmail.com \\ ${ }^{2}$ ernawatidunib.ac.id \\ ${ }^{3}$ rusdi.efendidunib.ac.id
}

\begin{abstract}
Abstrak. Permukiman kumuh merupakan lingkungan hunian atau tempat tinggal beserta lingkungannya, yang berfungsi sebagai rumah tinggal dan sebagai sarana pembinaan keluarga, tetapi tidak layak huni. Penentuan kualitas permukiman kumuh di Kota bengkulu dibagi menjadi empat tingkatan kekumuhan yaitu kumuh berat, kumuh sedang, kumuh ringan, dan tidak Kumuh. Dalam mengklasifikasi data pemukiman kumuh di kota bengkulu, perlu adanya basis data yang saat menyimpan seluruh data pemukiman kumuh dari 67 kelurahan di Kota Bengkulu. Basis data ini digunakan sebagai data rekap yang sudah di olah dari data KOTAKU. Untuk menentukan kualitas permukiman tersebut diperlukan 7 indikator sebagai acuan penentuan kualitas permukiman, dimana didalam 7 indikator tersebut terdapat 19 sub indikator. Tujuan Penelitian ini adalah (1) Mengimplementasikan Metode Fuzzy C-Means (FCM) pada Basis Data Klasifikasi Kualitas Permukiman Kumuh di Keluruhan se-Kota Bengkulu; (2) Membangun basis data kasus basis Kawasan Permukiman Tingkat Kelurahan se-Kota Bengkulu; dan (3) Membantu dan mempermudah Tim KOTAKU dalam penentuan tingkat kekumuhan. Dalam penentuan tingkat kekumuhan peneliti menggunakan metode Fuzzy C-Means. Hasil yang didapat dengan metode Fuzzy C-Means untuk penentuan klasifikasi berdasarkan kualitas permukiman terbagi menjadi 4 tingkatan kekumuhan yang memiliki akurasi sebesar $62.687 \%$ yang didapat dari hasil perbandingan data hasil kluster metode Fuzzy C-Means dengan data dari KOTAKU Kota Bengkulu.

Kunci : Permukiman Kumuh, Basis Data, Kelurahan Kota Bengkulu, KOTAKU (Kota Tanpa Kumuh), dan Fuzzy C-means.
\end{abstract}

Abstract. Slums are neighborhoods or dwellings and their neighborhoods, which function as residential houses and as a means of fostering families, but not habitable. Determination of the quality of slum settlements in the city of bengkulu is divided into four levels of slums of slums, heavy slums, slums light, and not slim. In classifying the slum data in the city of bengkulu, the need for a data base that aat keep all data slum of 67 urban villages in the city of Bengkulu. This database is used as a recap data that has been in though of data KOTAKU. To determine the quality of settlements required 7 indicators as a reference for determining the quality of settlements, which in the 7 indicators contained 19 sub indicators. The objectives of this research are (1) Implement Fuzzy C-Means Method
(FCM) in Database of Classification of Quality of Slum Settlement in Keluruh as Bengkulu City; (2) to build database of base case of Kelurahan Urban Village Area in Bengkulu City; and (3) Assist and facilitate Team KOTAKU in determining slum level. In determining the level of slum of researcher using Fuzzy C-Means method. The results obtained by Fuzzy C-Means method for the determination of the classification based on the quality of settlements is divided into 4 levels of slum that has an accuracy of $62.687 \%$ obtained from the results of comparison of clustered data of Fuzzy C-Means method with data from KOTAKU in Bengkulu City.

Keywords: Slums, database, Sub-district of Bengkulu City, KOTAKU (Town Without Slum), and Fuzzy C-means. 


\section{PENDAHULUAN}

Permukiman kumuh adalah lingkungan hunian atau tempat tinggal/rumah beserta lingkungannya, yang berfungsi sebagai rumah tinggal dan sebagai sarana pembinaan keluarga, tetapi tidak layak huni ditinjau dari tingkat kepadatan penduduk, sarana dan prasarananya, fasilitas pendidikan, kesehatan serta sarana dan prasarana sosial budaya masyarakat [1]

Kota Bengkulu mempunyai 9 kawasan permukiman tingkat kecamatan dan 67 kawasan pemukiman tingkat kelurahan, data ini didapatkan dari lembaga Kota Tanpa Kumuh (KOTAKU) yang merupakan bagian dari Dinas Pekerjaan Umum Kota Bengkulu. Tujuan dari program KOTAKU adalah tidak ada lagi daerah kumuh di Kota Bengkulu yang menjadikan Nol persen kawasan kumuh pada tahun 2019.

Penentuan kualitas permukiman kumuh di Kota bengkulu dibagi menjadi empat tingkatan yaitu Kumuh Berat, Kumuh Sedang, Kumuh Rendah, dan Tidak Kumuh. Untuk menentukan tingkatan permukiman tersebut diperlukan 7 indikator sebagai acuan penentuan kualitas permukiman, dimana didalam 7 indikator tersebut terdapat 19 sub indikator (Kriteria). 19 kriteria digunakan untuk menentukan tingkat kekumuhan, semakin tinggi nilai kriteria tingkat kekumuhan ini maka semakin kumuh kelurahan tersebut.

Untuk melakukan klasifikasi data pemukiman kumuh di kota bengkulu perlu adanya basis data yang dapat mengolah seluruh data pemukiman kumuh dari 67 kelurahan di Kota Bengkulu. Data permukiman yang diolah oleh Tim KOTAKU jumlahnya banyak dan pengolahan data masih menggunakan excel, pengolahan data permukiman yang menggunakan excel memiliki kendala terutama waktu pengolahan. Sehingga, Basis data perlu dibuat sebagai alternatif data excel yang diperoleh dari Tim KOTAKU. Dengan adanya basis data, proses data lebih mudah dan dapat dilakukan sekali banyak.

Klasifikasi data tersebut dapat dilakukan dengan menggunakan metode Fuzzy C-Means (FCM). Fuzzy C-Means adalah suatu teknik pengelompokkan data yang keberadaan setiap titik data dalam suatu kluster ditentukan berdasarkan derajat keanggotaannya. Konsep dasar FCM, menentukan pusat kluster yang akan mengelompokkan setiap titik dalam suatu kelompok. Kondisis Pada pusat kluster dan titik setiap data berdasarkan derajat keanggotaan ini masih belum akurat. Sehingga pusat kluster dan nilai keanggotaan tersebut dilakukan secara berulang maka akan didapat bahwa pusat kluster akan bergerak ke lokasi yang tepat.

Berdasarkan uraian diatas maka penulis akan melakukan klasifikasi data kawasan pemukiman dengan menggunakan metode yang berbeda agar lebih efesien dalam memproses data. Dan dengan menggunakan metode Fuzzy C-Means Clustering ini dapat membantu Tim KOTAKU dalam pengelompokkan tingkat kekumuhan setiap Kelurahan yang ada di Kota Bengkulu.

\section{LANDASAN TEORI}

\section{A. Permukiman Kumuh}

Permukiman kumuh adalah lingkungan hunian atau tempat tinggal/rumah beserta lingkungannya, yang berfungsi sebagai rumah tinggal dan sebagai sarana pembinaan keluarga, tetapi tidak layak huni ditinjau dari tingkat kepadatan penduduk, sarana dan prasarananya, fasilitas pendidikan, kesehatan serta sarana dan prasarana sosial budaya masyarakat [1]. 


\section{B. KOTAKU (Kota Tanpa Kumuh)}

Program KOTAKU (Kota Tanpa Kumuh) adalah program pencegahan dan peningkatan kualitas permukiman kumuh nasional yang merupakan penjabaran dari pelaksanaan Rencana Strategis Direktorat Jenderal Cipta Karya. Pemerintah menetapkan penanganan perumahan dan permukiman kumuh sebagai target nasional yang dituangkan dalam Rencana Pembangunan Jangka Menengah Nasional (RPJMN) 2015-2019. Dalam RPJMN 2015-2019 disebutkan bahwa salah satu sasaran pembangunan kawasan permukiman adalah tercapainya pengentasan permukiman kumuh perkotaan menjadi sasaran program ini adalah tercapainya pengentasan permukiman kumuh perkotaan menjadi $0 \mathrm{Ha}$ melalui pencegahan dan peningkatan kualitas permukiman kumuh. Tujuan program adalah meningkatkan akses terhadap infrastruktur dan pelayanan dasar di kawasan kumuh perkotaan untuk mendukung terwujudnya permukiman perkotaan yang layak huni, produktif dan berkelanjutan. Manfaatnya adalah Meningkatnya akses masyarakat terhadap infrastruktur dan pelayanan perkotaan pada kawasan kumuh (drainase; air bersih/minum; pengelolaan persampahan; pengelolaan air limbah; pengamanan kebakaran; Ruang Terbuka Hijau/Publik), lalu menurunnya luasan kawasan kumuh karena akses infrastruktur dan pelayanan perkotaan yang lebih baik [2].

\section{Basis Data}

Basis data adalah kumpulan data yang disimpan secara sistematis di dalam komputer dan dapat diolah atau dimanipulasi menggunakan perangkat lunak (program aplikasi) untuk menghasilkan informasi Pendefinisian basis data meliputi spesifikasi berupa tipe data, struktur, dan juga batasan-batasan data yang akan disimpan.
Basis data merupakan aspek yang sangat penting dalam sistem informasi dimana basis data merupakan gudang penyimpanan data yang akan diolah lebih lanjut. Basis data menjadi penting karena dapat menghidari duplikasi data, hubungan antar data yang tidak jelas, organisasi data, dan juga update yang rumit [3].

\section{Logika Fuzzy}

Logia Fuzzy merupakan salah satu komponen pembentuk soft computing. Pada teori Himpunan fuzzy, peranan derajat keanggotaan sebagai penentu keberadaan elemen dalam suatu himpunan sangatlah penting. Nilai keanggotaan atau derajat keanggotaan atau membership function menjadi ciri utama dari penalaran dengan logikka fuzzy tersebut [4].

\section{E. Fuzzy C-Means Clustering}

Fuzzy C-Means (FCM) adalah suatu teknik pengclusteran data yang mana keberadaan tiap-tiap titik data dalam suatu cluster ditentukan oleh derajat keanggotaan. Fuzzy Clustering sangat berguna bagi pemodelan fuzzy terutama dalam mengidentifikasi aturan-aturan fuzzy [4].

Algoritma FCM adalah sebagai berikut :

1. Input data yang akan di cluster $\mathrm{X}$, berupa matriks berukuran $\mathrm{n} \times \mathrm{m}$ ( $\mathrm{n}=$ jumlah sampel data, $m=$ atribut setiap data). $X_{\mathrm{ij}}=$ data sampel ke-I (i=1,2,..,n), atribut ke-j $(j=1,2, . ., n)$.

\section{Tentukan :}
a. Jumlah Cluster
$=\mathrm{c}$
b. Pangkat
$=\mathrm{w}$;
c. Maksimum iterasi
= MaxIter;
d. Error terkecil yang diharapkan $=\xi$,
e. Fungsi objektif awal
$=\mathrm{P}_{0}=0$
f. Iterasi awal
$=\mathrm{t}=1$; 
3. Bangkitkan bilangan random $\mu \mathrm{i}_{\mathrm{k}}, \mathrm{i}=1,2, . ., \mathrm{n} ; \mathrm{k}=$ $1,2, \ldots, \mathrm{c} ;$ sebagai elemen-elemen matriks partisi awal U.

4. Hitung pusat cluster ke-k : $\mathrm{V}_{\mathrm{kj}}$ dengan $\mathrm{k}=1,2, \ldots, \mathrm{c} ;$ dan $\mathrm{j}=1,2, \ldots, \mathrm{m}$

$$
\mathrm{V}_{\mathrm{kj}}=\frac{\left.\sum_{i=1}^{n}\left(\left(\mu_{i k}\right)^{w_{*}} X_{i j}\right)\right)}{\sum_{i=1}^{n}\left(\mu_{i k}\right)^{w}}
$$

Keterangan :

Vkj = Pusat Kluster data ke- $i$ dan kriteria ke-j

$=$ Data ke- $i$ dan kriteria ke- $j$

$\mu i k=$ Bilangan random data ke- $i$ dan kriteria ke- $j$

$w \quad=$ Nilai pangkat

5. Hitung fungsi objektif pada iterasi ke-t, $\mathrm{P}_{\mathrm{t}}$ :

$\mathrm{P}_{\mathrm{t}}=\sum_{i=1}^{n} \sum_{k=1}^{c}\left(\left[\sum_{j=1}^{m}\left(X_{i j}-V_{k j}\right)^{2}\right]\left(\mu_{i k}\right)^{w}\right)$

Keterangan :

$P t=$ Fungsi objektif pada iterasi ke-t

$=$ Data ke-i dan kriteria ke- $\mathrm{j}$

$V k j=$ Pusat Kluster kluster ke-k dan kriteria ke-j

$\mu i k=$ Bilangan random data ke-i dan kriteria $\mathrm{ke}-\mathrm{j}$

$w=$ Nilai pangkat

6. Hitung perubahan matriks partisi :

$$
\mu \mathrm{i}_{\mathrm{k}}=\frac{\left[\sum_{j=1}^{m}\left(X_{i j}-V_{k j}\right)^{2}\right]^{\frac{-1}{w-1}}}{\sum_{k-1}^{c}\left[\sum_{j=1}^{m}\left(x_{i j}-V_{k j}\right)^{2}\right]^{\frac{-1}{w-1}}}
$$

Keterangan :

$\mu i k=$ Elemen matriks baru data ke-i dan

kluster ke-k

$X i j=$ Data ke-i dan kriteria ke-j

$V k j=$ Pusat Kluster ke-k dan kriteria ke-j

$w=$ Nilai pangkat
7. Cek kondisi berhenti :

- Jika : $(|\mathrm{Pt}-\mathrm{Pt}-1|<\xi)$ atau ( $\mathrm{t}>$ MaxIter) maka berhenti;

- Jika tidak : $\mathrm{t}=\mathrm{t}+1$, ulangi langkah ke-4.

\section{G. Codeigniter}

Codeigniter adalah salah satu dari sekian banyak kerangka kerja siap pakai (framework) berbasis PHP, jadi dengan menggunakan Codeigniter hanya tinggal memikirkan proses bisnisnya saja tanpa perlu memikirkan yang lain, karena fitur-fitur standar sudah tersedia di Codeigniter seperti pagging, validation, routing dan masih banyak lagi, hanya cukup dengan memanggilnya saja [5].

\section{METODOLOGI}

Langkah-langkah yang dilakukan dalam penelitian ini adalah :

1) Dokumentasi

Bahan utama dalam penelitian ini adalah dengan mengumpulkan data yang didapat dari TIM KOTAKU Kota Bengkulu seperti data total kelurahan dan data kriteria permukiman kumuh.

2) Wawancara

Penulis juga melakukan wawancara terhadap staf bagian pengolahan data di atas nama Ostop Tenasa, S.Kom. TIM KOTAKU Kota Bengkulu untuk mendapatkan penjelasan serta melakukan konfirmasi data sehingga data yang diperoleh diharapkan merupakan data yang akurat dan tepat.

3) Studi Pustaka

Studi pustaka dilakukan dengan cara menelaah beberapa literatur, yaitu Studi Pustaka dilakukan dengan cara mempelajari teori-teori literatur dan buku-buku yang 
berhubungan dengan aplikasi yang akan dibangun dalam penelitian ini.

\section{IV.ANALISIS DATA DAN PERANCANGAN}

\section{A. Identifikasi Masalah}

Sistem yang akan dibangun nantinya akan menggunakan Bahasa pemrograman PHP dengan framework Codeigniter dan Database Mysql. Untuk membangun suatu sistem perlu dilakukan analisis terlebih dahulu dari sistem itu sendiri. Hal ini merupakan hal yang penting karena hasil dari analisis tersebut akan berpengaruh pada pembangunan sistem itu sendiri. Berikut akan dijelaskan analisis data dan Sistem dalam penelitian ini.

Dalam mengidentifikasi kemungkinan penyebab masalah dengan menggunakan diagram Ishikawa. Diagram Ishikawa atau yang sering dikenal dengan Cause and Effect Diagram adalah diagram yang digunakan untuk memahami dan mengidentifikasi serta menggambarkan beberapa masalah yang terjadi pada sistem dan akibat yang ditimbulkan oleh masalah dapat ditunjukkan pada gambar 4.1.

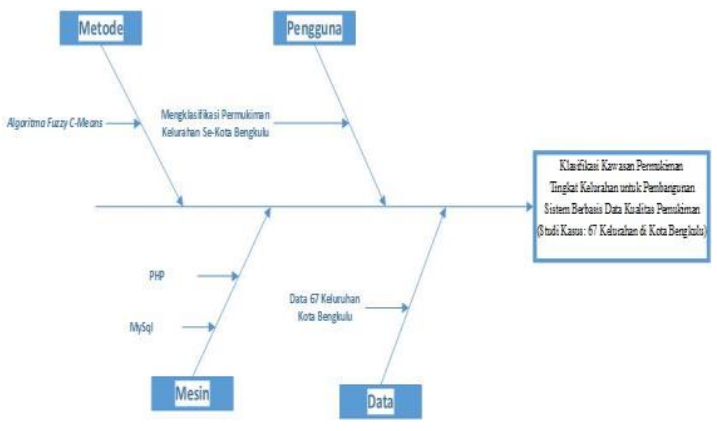

GAMBAR 4. 1 DIAGRAM ISHIKAWA

\section{B. Analisis Alir Kerja Sistem}

Alur sistem akan memudahkan dalam mengimplementasikan rancangan kedalam sistem yang akan dibangun dapat dilihat pada gambar 4.2 .

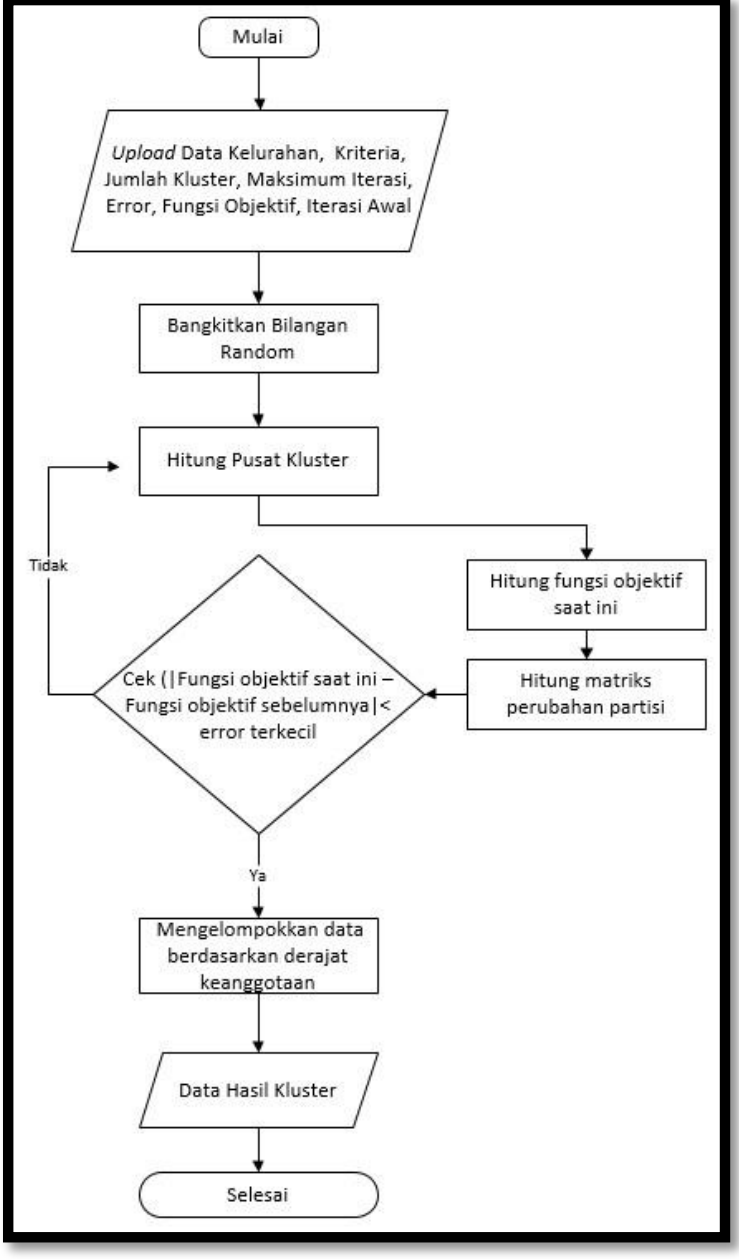

Gambar 4.2 Diagram Alir KerJa Sistem

C. Perancangan Sistem

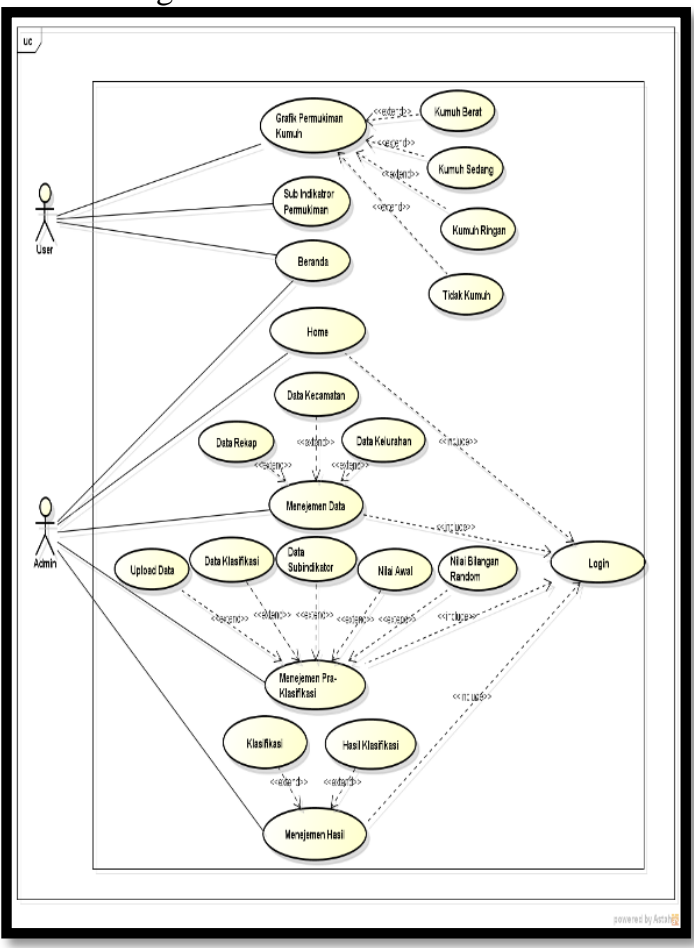

Gambar 4. 3 Use Case 


\section{PEMBAHASAN}

A. Implementasi Antarmuka

Setelah melakukan perancangan, maka selanjutnya adalah implementasi sistem menggunakan bahasa pemrograman PHP dan menggunakan framework Codeigniter.

a. Halaman Beranda

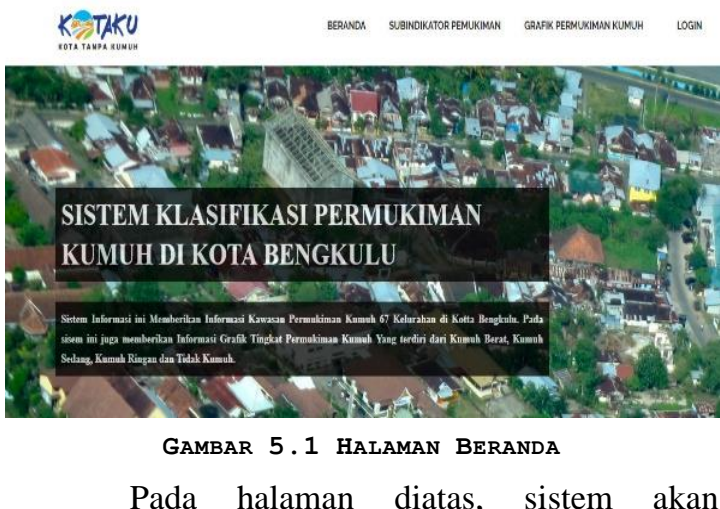
menampilkanhalaman awal KOTAKU berupa Beranda. Pada menu beranda atau halaman pertama ini beberapa menu yang dapat diakses antara lain menu sub indikator permukiman, grafik permukiman, dan login. Halaman ini merupakan halaman yang dapat diakses pengunjung dan admin yang dapat dilihat pada

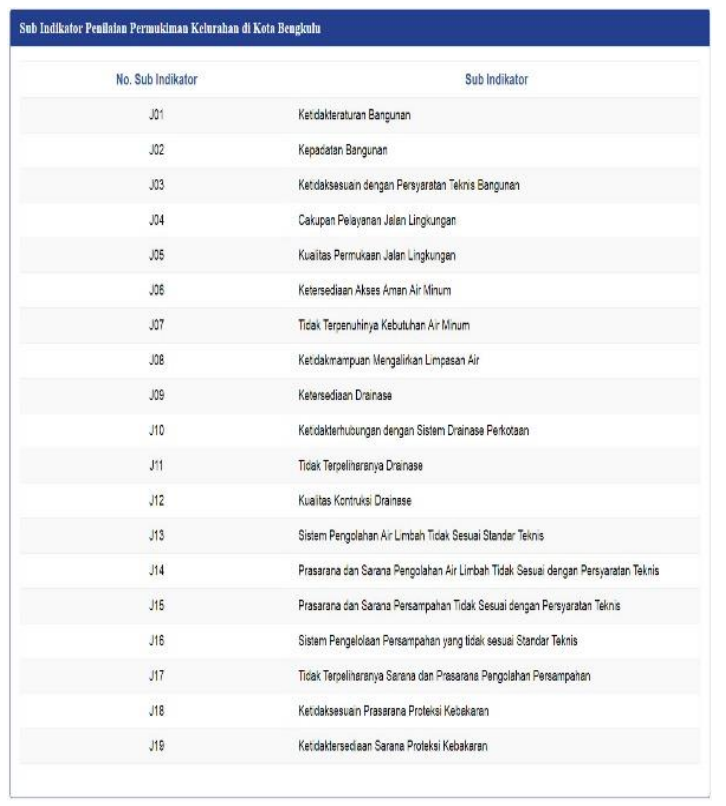

Gambar 5.1.Halaman Sub Indikator Permukiman b. Halaman Sub Indikator Permukiman

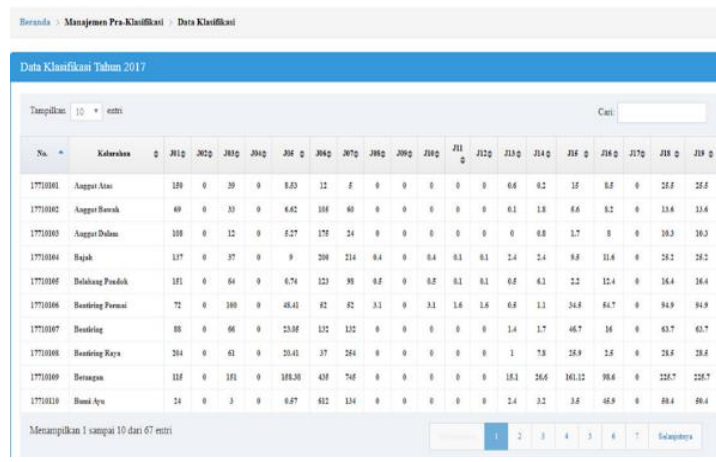

Gambar 5.2 HaLAman SUb INDIKATOR PERMUKIMAN

Pada halaman sub indikator Permukiman sistem akan menampilkan halaman acuan dalam menentukan penilaian tingkat kekumuhan sub indikator permukiman berdasarkan 19 sub indikator. Halaman ini merupakan halaman yang dapat diakses pengunjung dan admin yang dapat dilihat pada gambar 5.2. Halaman Sub Indikator Permukiman.

\section{c. Halaman Grafik Permukiman Kumuh}

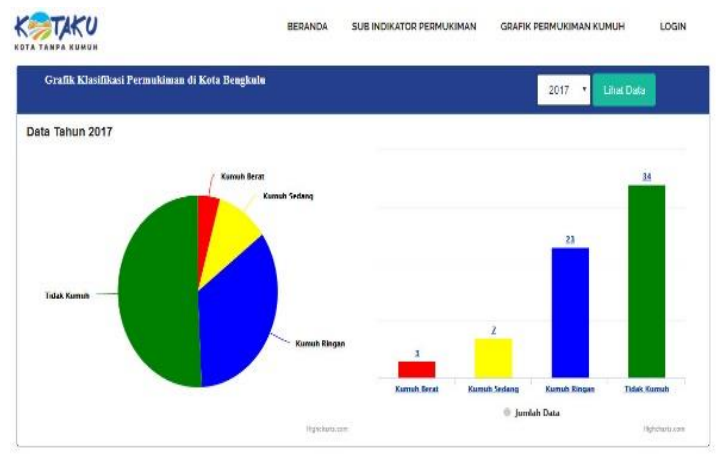

Gambar 5.3 halaman Grafik Permukiman Kumuh

Pada halaman grafik permukiman kumuh menampilkan hasil klasifikasi dari 4 kluster yaitu kumuh berat, kumuh sedang, kumuh ringan, dan tidak kumuh. Pada kumuh berat menunjukan warna merah, kumuh sedang warna kuning, kumuh ringan warna biru, dan tidak kumuh warna hijau yang menentukan tingkat kekumuhan. Halaman ini merupakan halaman yang dapat diakses admin dan pengunjung. Admin dan pengunjung dapat melihat hasil klasifikasi berdasarkan tahun yang di 
masukkan admin yang dapat dilihat pada gambar 5.3. Halaman Grafik Permukiman. Admin dan pengunjung dapat mengklik dropdown tahun dan menampilkan data dengan mengklik lihat data. Admin dan pengunjung dapat juga melihat kelurahan mana saja yang masuk kumuh berat, kumuh sedang, kumuh ringan, dan tidak kumuh dengan cara mengklik grafik klasifikasi permukiman yang dapat dilihat pada gambar 5. 3 Halaman sample klik data Kelurahan kumuh berat.

\section{d. Halaman Home}

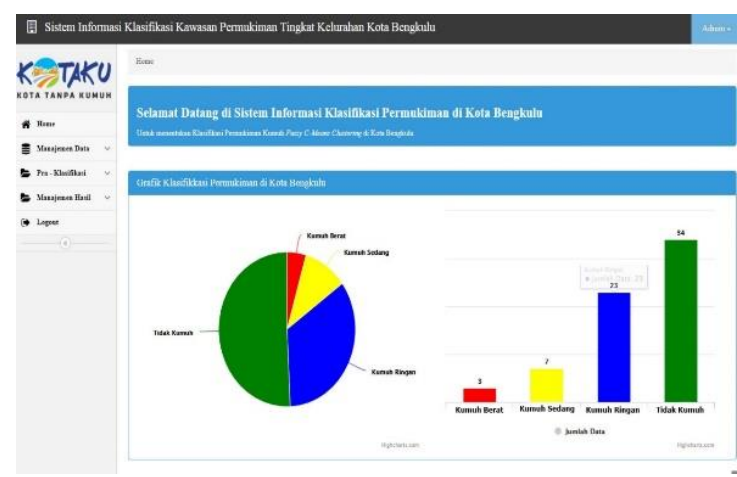

Gambar 5. 4 halaman Grafik Permukiman KumuH

Pada Halaman awal setelah melakuakan Login Klasifikasi merupakan Halaman Menu Home. Halaman ini merupakan halaman yang hanya dapat diakses oleh admin Tim KOTAKU. Pada Halaman ini menampilkan hasil klasifikasi didapat dari data nilai numerik sub indikator dari 67 Kelurahan yang ada di Kota Bengkulu. Pada Halaman awal setelah melakukan login, admin dapat mengakses halaman manajemen data yang berisi data kecamatan, data kelurahan, dan data rekap. Kemudian admin dapat mengakses praklasifikasi yang berisi upload data, data klasifikasi, data sub indikator, nilai awal, dan nilai bilangan random. Setelah itu admin dapat mengakses manajemen hasil yang berisi klasifikasi dan hasil klasifikasi. Warna yang ada pada grafik menunjukkan kumuh berat warna merah, kumuh sedang warna kuning, kumuh ringan warna biru, dan tidak kumuh warna hijau yang menentukan tingkat kekumuhan yang dapat lihat pada gambar 5.4 Halaman Home.

\section{e. Halaman Upload Data}

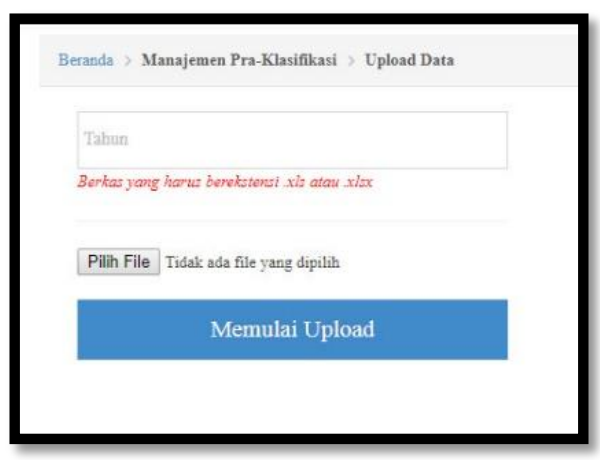

Gambar 5.5 halaman Upload Data

Pada halaman upload Data merupakan submenu dari manajemen Pra-Klasifikasi. Halaman ini merupakan halaman yang hanya dapat diakses oleh admin Tim KOTAKU . Pada Halaman upload data menampilkan data tahun yang harus dimasukan ke dalam sistem berupa data 67 Kelurahan di Kota Bengkulu saat memilih file berupa data excel. Setelah data/file sudah dipilih admin, admin menekan tombol memulai upload yang akan masuk datanya ke data klasifikasi yang dapat lihat pada gambar 5.5 Halaman Upload Data.

\section{f. Halaman Data Klasifikasi}

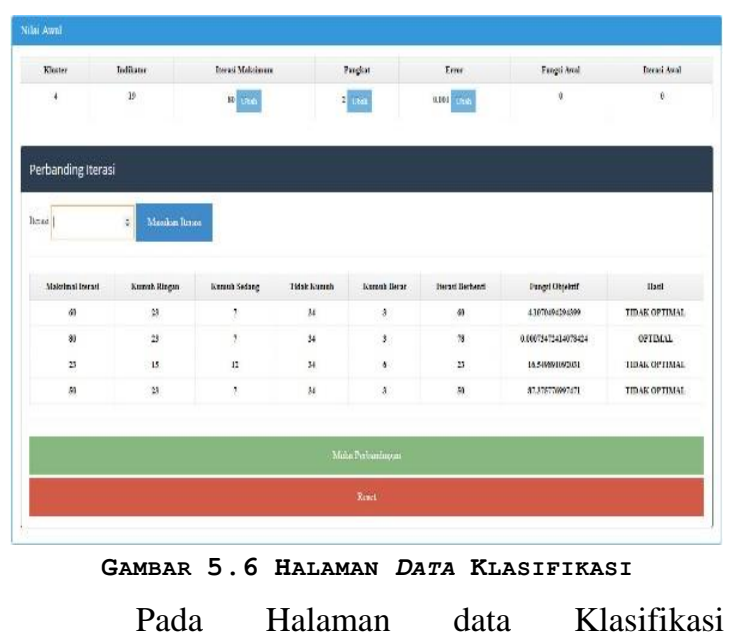

merupakan submenu dari manajemen praklasifikasi. Halaman ini menampilkan data nilai 
numerik sub indikator dari 67 Kelurahan yang ada di Kota Bengkulu. Halaman data klasifikasi ini merupakan data awal yang akan digunakan untuk mengklasifikasi Kelurahan yang ada di Kota Bengkulu menjadi 4 kluster yaitu kumuh berat, kumuh sedang, kumuh ringan, dan tidak kumuh. Halaman ini merupakan halaman yang hanya dapat diakses oleh admin Tim KOTAKU yang dapat dilihat ada gambar gambar 5.6 Halaman Data Klasifikasi.

\section{g. Halaman Nilai Awal}

Pada halaman nilai awal merupakan submenu dari manajemen Pra-Klasifikasi. Halaman ini merupakan halaman yang hanya dapat diakses oleh admin Tim KOTAKU. Pada Halaman ini menampilkan memasukan dari nilai awal sebagai parameter fuzzy c-means yang untuk digunakan dalam pengklasifikasian 67 Kelurahan diKota Bengkulu. Pada halaman nilai awal menampilkan 4 jumlah kluster, 19 sub indikator, 80 iterasi, 2 pangkat, dan error terkecil 0,001. Pada jumlah kluster ditetapkan 4 tingkat kekumuhan dari Tim KOTAKU yaitu kumuh berat, kumuh sedang, kumuh ringan, dan tidak kumuh. Kemudian pada nilai pangkat yang digunakan adalah 2, yang berarti setiap nilai random yang digunakan dalam setiap perhitungan akan dipangkatkan dengan 2. Pada maksimun iterasi ditetapkan 80 iterasi dan nilai error terkecil ditetapkan 0,001 karena semakin banyak maksimun iterasi dan semakin kecil error hasil pusat kluster akan berada pada posisi yang tepat. Pada Iterasi awal dimulai dari 1 sehingga memudahkan dalam pengecekan nilai awal dan nilai perhitungan setiap iterasi. Namun pada iterasi pertama, nilai fungsi objektif tidak memiliki nilai pembanding dengan iterasi sebelumnya sehingga ditetapkan nilai $\operatorname{Po}(0)$ sebagai pembanding di awal.

Pada halaman Nilai awal terdapat pembanding iterasi yang berguna untuk membandingkan iterasi yang optimal. Admin dapat memasukkan iterasi untuk mengetahui iterasi yang didapat optimal atau tidak dengan mengklik masukan iterasi kedalam table. Pada table perbandingan iterasi yang berisi maksimum iterasi, kumuh ringan, kumuh sedang, tidak kumuh, kumuh berat, iterasi berhenti, fungsi objektif dan hasil. Setelah admin memasukkan data maksimum iterasi, admin mengklik mulai perbandingan yang dapat lihat pada gambar 5.7. Halaman Nilai awal. Admin Tim KOTAKU dapat menghapus semua data perbandingan iterasi dengan klik tombol reset.

\section{h. Halaman Nilai Bilangan Random}

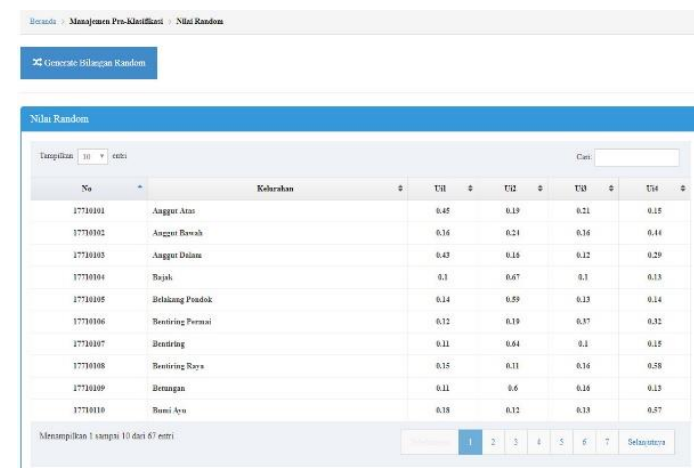

Gambar 5.8 halaman NILAI BILANGAN RANDOM

Pada halaman nilai bilangan random merupakan submenu dari manajemen PraKlasifikasi. Pada Halaman ini menampilkan masukan nilai dari parameter fuzzy c-means yang berguna dalam penentuan pusat cluster sangat mempengaruhi proses perhitungan dalam menentukan kedekatan nilai terhadap pusat. Pada halaman ini memiliki tombol generate bilangan random yang digunakan untuk membangkitkan bilangan random secara acak dalam penentuan pusat cluster. Halaman ini merupakan halaman yang hanya dapat diakses oleh admin yang dapat 
lihat pada gambar 5.8 Halaman Nilai Bilangan Random dan Lampiran 7 Data Nilai Bilangan Random secara keseluruhan.

\section{i. Halaman Klasifikasi}

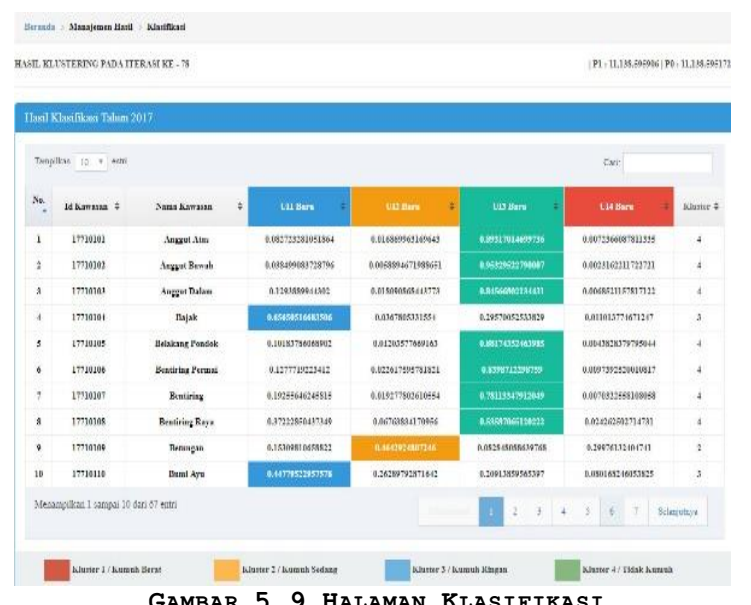

Gambar 5.9 halaman KLASIfikasi

Pada Halaman klasifikasi merupakan submenu dari manajemen hasil. Halaman ini merupakan halaman yang hanya dapat diakses oleh admin Tim KOTAKU. Pada Halaman ini menampilkan hasil yang didapat dari metode fuzzy c-means berupa kelurahan 4 kluster yaitu kumuh berat, kumuh sedang, kumuh ringan, atau tidak kumuh. Pada halaman ini terdapat hasil kluster yang berhenti pada iterasi ke-78 karena selisih nilai fungsi objektif pada iterasi saat ini (P1) dengan fungsi objektif sebelumnya (P0) lebih kecil dari 0,001. Hasil derajat keanggotaan baru dapat dilihat dari nilai yang paling besar pada setiap kelurahan dan warna pada table menunjukkan kumuh berat berwarna merah, kumuh sedang berwarna kuning, kumuh ringan berwarna biru, dan tidak kumuh berwarna hijau yang menentukan tingkat kekumuhan. Pada table yang tidak diberi warna tidak masuk klasifikasi dikarenakan nilai satu yang terbesar pada 4 kluster yang diambil untuk menentukan tingkat kekumuhan suatu Kelurahan yang ditandai dengan warna biru, kuning, hijau atau merah. Pada kolom Ui1 baru menunjukan informasi kumuh ringan, Ui2 Baru menunjukan informasi kumuh sedang, Ui3 Baru menujukan informasi tidak kumuh dan Ui4 Baru menunjukan kumuh berat. Pada table kluster menunjukan angka 1, 2, 3, 4 yang menujukkan suatu Kelurahan masuk ke kluster 1 (Kumuh Berat), kluster 2 (Kumuh Sedang), kluster 3 (Kumuh Ringan), atau 4 (Tidak Kumuh) yang dapat dilihat pada gambar 5.9. Halaman klasifikasi.

\section{j. Halaman Hasil Klasifikasi}

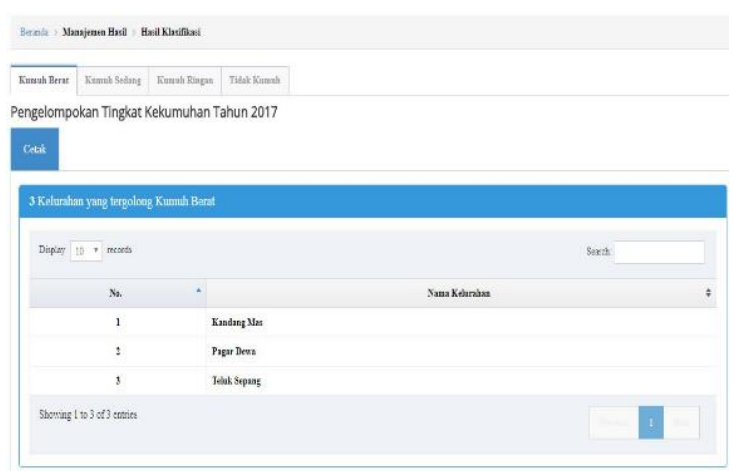

Gambar 5.10 HaLAMAN HASIL KLASIFIKASI

Pada Halaman hasil kluster merupakan submenu dari manajemen hasil. Pada Halaman ini menampilkan hasil yang telah diklasifikasi berdasarkan kelurahan mana yang masuk kumuh berat, kumuh sedang, kumuh ringan, ataupun tidak kumuh. Pada halaman ini telah terkelompok berdasakan tingakat kekumuhan pada 67 Kelurahan di Kota Bengkulu. Pada halaman ini admin dapat mencetak hasil klasifikasi yang telah terklasifikasi berdasarkan tingkat kekumuhan. Halaman ini merupakan halaman yang hanya dapat diakses oleh admin Tim KOTAKU yang dapat dilihat pada gambar 5.10. Halaman Hasil klasifikasi. 


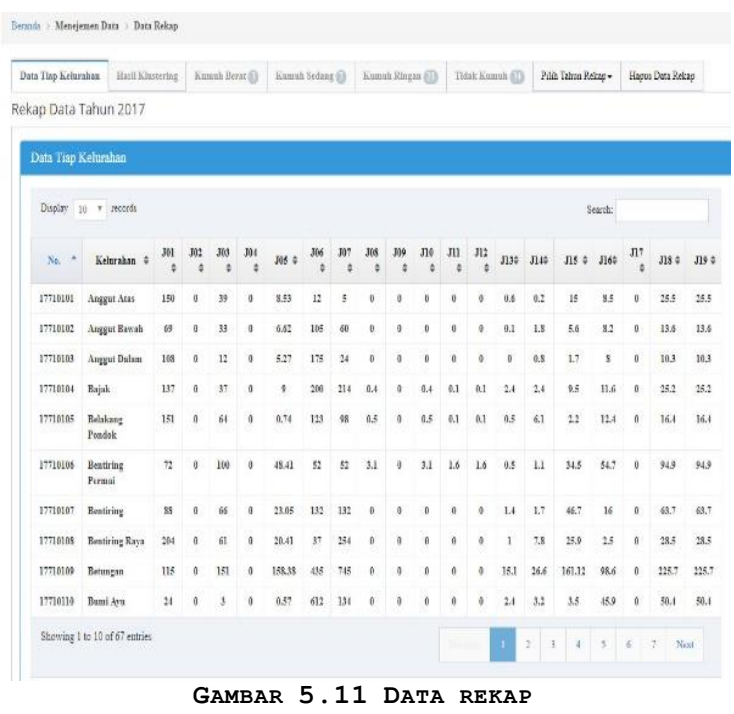

Pada Halaman rekap data merupakan submenu dari manajemen data. Halaman ini menampilkan data nilai numerik sub indikator dari 67 Kelurahan yang ada di Kota Bengkulu berdasarkan tahun yang telah di upload. Halaman data rekap ini dapat melihat dan menghapus data yang telah dimasukkan kedalam sistem sebelum dan sesudah data dimasukkan kedalam sistem. Admin dapat melihat hasil yang telah diklasifikasi berdasarkan tingkat kekumuhan yaitu kumuh berat, kumuh sedang, kumuh ringan, dan tidak kumuh yang akan menampilkan data pada tahun yang dipilih oleh admin. Halaman ini merupakan halaman yang hanya dapat diakses oleh admin Tim KOTAKU yang dapat dilihat ada gambar gambar 5.11. Halaman Data Rekap.

\section{B. Pengujian Sistem}

Pada penelitian ini, pengujian yang dilakukan dengan teknik pengujian black box yang dilakukan pada penelitian ini adalah teknik equivalence partitioning, yaitu teknik pengujian yang membagi domain input dari suatu program ke dalam kelas data, menentukan kasus pengujian dengan mengungkapkan kelas-kelas kesalahan, sehingga akan mengurangi jumlah kasus pengujian. Pengujian dilakukan dengan seluruh button pada setiap halaman. Total kelas uji 18 halaman pada sistem, dengan total 28 skenario pengujian. Dari seluruh kelas uji dan scenario pengujian, semua fungsi berhasil berjalan dengan baik sehingga keberhasilan fungsional sistem dapat dinilai sebesar $100 \%$.

\section{KESIMPULAN}

Berdasarkan penelitian dan pembahasan hasil yang sudah dilakukan, maka terdapat beberapa kesimpulan yang diperoleh dari penelitian ini, diantaranya sebagai berikut:

1. Penelitian ini telah berhasil melakukan klasifikkasi berdasarkan 7 indikator dan 19 sub indikator dari TIM KOTAKU Kota Bengkulu.

2. Penerapan metode Fuzzy C-Means untuk penentuan klasifikasi berdasarkan kualittas permukiman terbagi menjadi 4 kluster yaitu kumuh berat, sedang, ringan dan tidak kumuh yang memiliki akurasi sebesar $62.687 \%$ yang didapat dari hasil perbandingan data hasil kluster metode Fuzzy C-Means dengan data dari KOTAKU (Kota Tanpa Kumuh) Kota Bengkulu.

3. Hasil klasifikasi menunjukkan rata-rata kelurahan permukiman di Kota Bengkulu dengan hasil yaitu 3 kumuh berat, 7 kumuh sedang, 23 Kumuh ringan, dan 34 tidak kumuh kelurahan.

4. Semua fungsi kelas uji dan scenario pengujian berhasil berjalan dengan baik sehingga keberhasilan fungsional sistem dapat dinilai sebesar $100 \%$, dinilai dari kelas uji 18 halaman pada sistem, dengan total 28 skenario pengujian. 
5. Dengan ada basis data kita dapat melihat informasi data permukiman kumuh perkelurahan se-kota Bengkulu.

\section{SARAN}

Berdasarkan analisa dan perancangan sistem, implementasi, dan pengujian sistem, maka saran yang dapat diberikan untuk pengembangan penelitian selanjutnya adalah sebagai berikut:

1. Tingkat akurasi berbeda dengan Tim KOTAKU karena memakai perbandingan dengan jumlah data keseluruhan sedangkan Fuzzy C-Means dengan bobot yang ada di algoritma dan iterasi optimal dalam mendapakan tingkat kekumuhan.

2. Bilangan random berpengaruh pada perubahan seluruh data sebagai kekurangan Fuzzy C-Means.
3. Saran metode lain yang lebih baik yang bisa menangani kelemahan Fuzzy C-Means, seperti menggunakan metode penggabungan (hybrid) yaitu Subtractive Fuzzy C-Means (SFCM).

\section{REFERENSI}

[1] I. Andini, "Sikap dan Peran Pemerintah Kota Surabaya Terhadap Perbaikan Daerah Kumuh di Kelurahan Tanah Kalikedinding Kota Surabaya,” 2013.

[2] Karya, "Draft Petunjuk Pelaksanaan KOTAKU Tingkat Kota," 2016.

[3] Fathansyah, Basis Data Edisi Revisi, Bandung: Informatika, 2012.

[4] S. Kusumadewi dan H. Purnomo, Aplikasi Logika Fuzzy Untuk Pendukung Keputusan, Yogyakarta: Graha Ilmu, 2010

[5] A. Julisman, Sistem Aplikasi Travel dengan angularJS \& CodeIgniter, Yogyakarta: Lokomedia, 2014. 